\title{
Existences of Ketoprak as Indonesian Performing Art: An Issue in Tradition and Modernization Perspective
}

\author{
Chafit Ulya, Nugraheni E. Wardani \\ Sebelas Maret University \\ chafit@staff.uns.ac.id
}

\begin{abstract}
Modernization has brought an enormous impact on the existence of traditional art in Indonesia with ketoprak performance as no exception. This study aims to discover the preserved elements of tradition and the modified elements of tradition in accordance with the demands of the times. This is a descriptive qualitative in which produces descriptive data in the form of verbal or written words of people and observable behaviors. It is concluded that ketoprak has a flexible nature to change the pattern of performance. The elements of tradition and modernization need to be combined in ketoprak performance as an effort to maintain the existence of the traditional performing arts. In the ketoprak performance, traditional preserved elements include gandrung (love), perangan (fight), and dagelan (jokes); clothing and Javanese language, as well as balungan lakon or improvised methods. Meanwhile, modern elements are included in supporting elements such as lighting, music and stage programming, as well as major elements in the form of stories. This combination shows that ketoprak art performances have the flexibility to make changes. This is what makes the existence of ketoprak performance art still remain.
\end{abstract}

Keywords: Ketoprak; Indonesian Performing Art; Tradition; Modernization; Existences

\section{INTRODUCTION}

Modernization has brought an enormous impact on the existence of traditional art in Indonesia with ketoprak performance as no exception. Advances in technology have led to the emergence of more exciting and easy-to-use entertainment choices. The tastes and needs of the community for entertainment have also changed. Consequently, traditional art-based entertainment has also begun to be abandoned.

This situation requires traditional art to consider the tradition. Dialectics between tradition and modernization must be harmonized. A rigid understanding of tradition will only make traditional art more abandoned. On the contrary, following the modernization will make deprived of original cultural. Therefore, there must be a balance between maintaining traditional values and modernizing traditional values.

In the context of traditional ketoprak art performances, the process of considering this tradition also applies. The combination of traditional elements with modernization needs to be organized so that the existence of this traditional theater can stay preserved. It takes a study to 
explore the values of tradition that must be maintained and the values of modernization which can be inserted.

Therefore, this study is intended to give an overview of the elements of ketoprak performance that is firm and flexible. The elements of firmness are the elements to be maintained, while flexibility elements are the openness for change. This phenomenon changes the pattern of performance is the focus in this study. With this study, it is expected that ketoprak performance will continue to have a strategic role and side for the development of Indonesian art and culture.

\section{METHOD}

The form of this study is descriptive qualitative in which produces descriptive data in the form of verbal or written words of people and observable behaviors[1]. The research approach used was a case study that attempted to examine as much data as possible on the subject being investigated to describe a case in detail. Case studies fit well when the focus of the research lies in contemporary phenomena (present-day) in the real-life context [2].

The type of data collected in this study consisted of three things, namely words, actions, and documents. The three types of data were taken or collected from sources of information in the form of informants, places and events, and documentation. Sampling technique was by using purposive sampling technique and snowball sampling technique. Data collection techniques consisted of three ways, namely observation, interview, and document analysis. Collected data needed to be validated to obtain accurate data and prove the accuracy through triangulation of sources, method triangulation, and review of informants. The data collected were then analyzed systematically. Meanwhile, the analysis of the data was based on Miles and Huberman views which presented an interactive analysis model consisting of three stages, namely data reduction, data presentation, and concatenation/verification [3].

\section{RESULT AND DISCUSSION}

Ketoprak is one of the theater performances originated from Java. Born, grow, and develop from Javanese culture. History of ketoprak development had been recorded in long form of oral verbal, documentation, and scientific studies. The dynamics and social change of society also give color to the ketoprak development.

In dealing with current global situation, the existence of ketoprak is facing hard path. The ketoprak performance has to deal with various entertainment options presented through various media with a more attractive look and accessible. Meanwhile, ketoprak performance is static, unable to follow the ever-growing movement of times. Therefore, it takes a special strategy to maintain the noble values contained in ketoprak performances so it will be well preserved time by time.

Several studies on the existence of many traditional performing arts were performed. One is the research done by Mubah. According to his research findings, in order to maintain the noble 
values of local culture in the traditional performing arts of globalization and modernization, strategies are needed, among others, the development of national identity to strengthen it, understanding the philosophy of culture to the whole community, protecting local culture, and utilizing information technology to introduce local culture to the world community [4]

To cope with this global situation, the government has a great role to participate in maintaining the existence of traditional arts. Suneki explains the importance of government's role in the business [5]. According to Suneki, the role of government is inseparable from the context of maintaining traditional values. The government needs to restore its function as a protector of traditional arts without having to interfere in the aesthetic process. This cannot be relegated to the fact that the government and its political system are largely influenced by efforts to preserve the traditional values of the modernization and industrialization demands [6]

Despite the government's intervention, the performers of traditional art should also have an awareness of the time changes. Traditional performers also need to actively respond to the phenomenon of enthusiasm changes to the type of entertainment. Research conducted by Supardan, et al. found this phenomenon at Cirebon theater performing arts. Various efforts had been made by the art and government performers to maintain one of Cirebon's typical artistic traditions. However, the results had not been running optimally. Cirebon's performing arts was threatened with its existence as a result of its watchers[7].

The situation of the ketoprak group is no different. Sitowati's research showed that similar situations were experienced by the Kethoprak Tobong Kelana Bhakti Cultural group. In the midst of modernization, the group searched for sustaining its existence through various efforts, among others was implementing family principles within the group, implementing flexible rules, seeking sponsorship assistance, and promoting the group through various artistic forms. To be able to survive, they even had to look for other jobs, such as crafting or becoming a wedding singer [8].

In East Java, ludruk performances also experience this. This statement is based on Alim's research results, et al. which resulted in the discovery that the fall of the existence of ludruk in East Java was a result of globalization that had changed the perspective of the artistic tastes of society [9]. In line with the conditions of some of these traditional arts, the common problems experienced by most traditional art groups in Indonesia are clearly described in Ahimsa-Putra's research. According to Ahimasa-Putra, some efforts should be put on to developing traditional art in Indonesia, such as the infamous traditional art among society, the lack of regeneration, the lack of government support, the absence of a master plan of traditional art development, and the low quality of traditional art. In matter of fact, traditional arts have several important functions for society, namely as tourist attractions, as a community identity, as well as a source of inspiration for the creation and development of new art [10].

Ali Imron, Nasucha, and Prayitno state that there are five constraints faced by traditional art for reactualization, namely the artistic performance (less varied storytelling, conventional staging technology; less professional performance management); The process of inheriting a less conducive artistic value; pouring it with communication technology and mass media; And shifting the values of life in society that implies the declining public appreciation of traditional art [11].

Looking at the situation, the revitalization measures of traditional art can be performed, among other things, to pack traditional art into a spectacular yet efficient spectacle by not abandoning its artistic value, while still staging the original artistic performing arts; Featuring 
guest stars in staging, applying professional management in staging traditional performing arts; The process of inheritance of more traditional and programmed traditional artistic values through educational institutions (schools); And synchronized synergies between the Tourism Department and the performing arts community and related parties by frequent joint meeting to create a conducive climate for the empowerment of traditional arts in the development of tourism in Surakarta.

Those efforts should be accomplished by all the traditional art groups in Indonesia, not to mention ketoprak. Ketoprak must be able to take on the positive side of modernization in order to increase the quality of the show and the appreciation of society without abandoning the noble values of an essential tradition. The flowing modernization will only make traditions uprooted from its nature root. That is, traditional art will turn into a popular culture and lose its traditional values [12].

Therefore, in the process of acculturation of this culture, traditional art performers must carefully choose between the elements of tradition and modernization in order to maintain the existence of traditional art. In this case, the development of keroncong music in Indonesia can be a good model of learning. Keroncong music can be metamorphosed into campursari music as a new variant giving color to the traditional music development [13].

The process of cultural acculturation should not undermine the basic essence of traditional performing arts. Therefore, performers should have an understanding of the essential elements that must be maintained and complementary elements that are open to changes. In relation to this, Widayat states that since its birth, ketoprak has undergone various fundamental changes, even once entered the electronics as a medium of modern information. This is inseparable from the flexible nature of ketoprak in responding to change. Thus, addressing this association with this global culture, it must have adapted to the changes.

One of the elements that can be absorbed is the production management and utilization of the supporting technology. In relation to production management, Pilkington states that one of the values of absorbed modernization is to adopt the management of contemporary theater groups and reduce traditional theater conventions. In addition, to support the process of regeneration and inheritance of traditional values, the textual approach is one of the efforts that can be taken into account [14]. One of the features of traditional performing arts is the pattern of non-text play. That is, no written scripts are used as guidelines. This is an important suggestion proposed by Sudarmoko in his research. According to him, one of the strategies that can be taken into account in preserving traditional values is to reproduce traditional literature in order to reach readers or viewers more widely range [15].

Meanwhile, in relation to the utilization of staging technology, Subanar's research can be used as a reference. The study successfully mapped the development of ketoprak today in Yogyakarta. According to him, ketoprak is no longer old-fashioned performance, more modern, more advanced, and more explorative. He discovered the presence of technological elements in ketoprak performances, such as the use of multimedia. This is what Garasi Theater is doing based on the concept of its performance on traditional values but with modern packaging. This is performed based on the tastes and needs of the majority of the younger audience [16].

Some of the above descriptions show that the elements of tradition can be combined with modernization. This is nothing but an effort to maintain the existence of traditional performing arts in Indonesia. 
One of the Ketoprak groups that is able to maintain its existence is Ketoprak Ngampung Balekambang. In every show, this group is able to combine the elements of tradition with modernization. The elements of tradition that are defended are gandrung, perangan (limbs), and dagelan (jokes). The three elements are considered to be maintained in the Ketoprak Ngampung show. The view is in line with Hatley's statements that important elements in ketoprak are love, war, and humor[16].

In addition to these three elements, Ketoprak Ngampung still bases on the Javanese tradition and culture in the change of shape. This is particularly seen through Javanese dialogue and typical Javanese fashion. Although the language is no longer a bit of a language in conventional ketoprak, but the spoken language level is still used. Language elements are recognized as an important part of the ketoprak so it is obligatory to maintain. Meanwhile, performers look dressed in Javanese dress or costume, in the form of lurik, blangkon, kebaya, and so forth.

Visually, the dramatization element appears in the use of lighting technology that adopts modern theater form. In a sad scene, the stage is lighted with blue. In an angry scene, the stage color turns red. Such a dramatization is commonly found in modern theater and Ketoprak Ngampung has incorporated the modern elements into this show.

The choice of merging modern elements and traditions in Ketoprak Ngampung is packaged in a simple story. This story is no longer historical, such as Babad Mataram, or adaptation of outside stories, such as Sam Pek Eng Tay, but about the stories of everyday life, such as about the wrong education of children. This theme is very common in everyday life. Only, the delivery of the contents of the story is packed symbolically.

Ketoprak Ngampung chose supporting elements as the developed object. In the meantime, the essence and substance of the ketoprak's essence are considered to be preserved unchanged. One of the things that unchanged in Ketoprak Ngampung is an improvised method. The biggest difficulty of players in Ketoprak Ngampung is playing with text or script. They are more accustomed to playing without texts. So, the method of expressing is still carried out by prioritizing balungan lakon (balungan play) as its guide.

The basic thing that Ketoprak Ngampung intention by choosing to enter the villages is to introduce the community to the form of a more simple, easier and more affordable ketoprak show, and cheaper in financial This effort is taken so people have the courage to play back ketoprak. At least in every village, there are one or two groups of ketoprak. If this is the case, the ketoprak will be able to reach the attention of the community again so that its preservation will remain exist.

In general, there are five characteristics of ketoprak delivered by Harymawan, namely (1) ketoprak using the Javanese language as the medium of instruction in dialogue; (2) stories are not tied to one of the writings, but there are three categories of divisions, namely traditional stories, narrative stories, and present stories; (3) the accompanying music is Javanese gamelan; (4) the whole story is divided into big and small stages and does not apply the flashback; And (5) there is a role of joke following protagonists and antagonists[17].

Of the five elements, there are elements that must be maintained and there is a supporting element that can be modified. The ability to integrate these two elements is the key to maintaining the existence of ketoprak performance art, as has been done by Ketoprak Ngampung Balekambang. 


\section{CONCLUSSION}

From the results of this study, it can be concluded that the elements of tradition and modernization need to be combined in ketoprak performance as an effort to maintain the existence of the traditional performing arts. In the Ketoprak Ngampung Balekambang show, traditional preserved elements include gandrung, perangan (limbs), and dagelan (jokes); clothing and Javanese language, as well as balungan play or improvised methods. Meanwhile, modern elements are included in supporting elements such as lighting, music and stage programming, as well as major elements in the form of stories. This combination shows that ketoprak art performances have the flexibility to make changes. This is what makes the existence of ketoprak performance art still remain.

\section{REFERENCES}

[1] L. J. Moleong, Metodologi Penelitian Kualitatif. Bandung: Remaja Rosdakarya, 2002.

[2] R. K. Yin, Studi Kasus (Desain dan Metode). Jakarta: PT Raja Grafindo Persada, 1992.

[3] M. B. Miles and A. M. Huberman, Analisis Data Kualitatif. Jakarta: UI-Press, 1992.

[4] A. S. Mubah, "Strategi Meningkatkan Daya Tahan Budaya Lokal dalam Menghadapi Arus Globalisasi," Masyarakat, Kebudayaan, dan Polit., vol. 24, no. 4, pp. 302-308, 2011.

[5] S. Suneki, "Dampak Globalisasi terhadap Eksistensi Budaya Daerah," J. Ilm. Civ., vol. 2, no. 1, pp. 307-321, 2012.

[6] R. Lanjari, "Political Practice and Its Implication on Folk Art Marginalization (Case Study of Wayang Orang/ Human Puppet Ngesti Pandhowo)," Harmon. J. Arts Res. Educ., vol. 16, no. 2, p. 163, Jan. 2017.

[7] D. Supardan, D. Saripudin, and A. B. Santoso a S. Muis, "The Cirebonan Theatrical Performing Art in The Middle of Globalization Exposure," Hist. Int. J. Hist. Educ., vol. 14, no. 2, 2013.

[8] I. Sitowati, "Existence, Identity and Survive Strategy Kethoprak Tobong Kelana Bhakti Budaya," Int. J. Creat. Arts Stud., vol. 2, no. 1, p. 63, Feb. 2017.

[9] M. S. Alim, "Existence Ludruk Sidoarjo Art in The Midstof Globalization Years 1975 1995," Genta, vol. 2, no. 2, pp. 194-206, 2014.

[10] H. S. A. Putra, "Fenomenologi Agama: Pendekatan Fenomenologi untuk Memahami Agama,” Walisongo J. Penelit. Sos. Keagamaan, vol. 20, no. 2, pp. 271-304, 2012.

[11] Y. I. A. Ma'ruf, N. a H. J, and Prayitno, "Revitalization of Traditional Performing Arts for Supporting Tourism in Surakarta," J. Penelit. Hum., vol. 6, no. 2, pp. 207-220, 2005.

[12] B. Sudardi, "The Rise Up Art Tradition in The Popular Culture," J. Educ. Soc. Sci., vol. 5, no. 2, pp. 42-58, 2016.

[13] L. S. a W. Triwinarti, "The Dynamics of Keroncong Music in Indonesia, 1940's 2000's," Tawarikh Int. J. Hist. Stud., vol. 5, no. 1, pp. 91-102, 2013.

[14] L. Pilkington, "The Pitfalls of Theatrical Consciousness," Krit. Kult., vol. 21, no. 22, pp. 1-10, 2014.

[15] Sudarmoko, "Republishing Folktales Their Audiences, Readers, and Influences in Modern Indonesian Literature," Krit. Kult., vol. 27, no. 27, pp. 125-150, 2016.

[16] B. Hatley, Javanese Performances on an Indonesian Stage: Contesting Culture, Embracing, Change, Singapore. US Press, 2008. 
[17] R. M. A. Harymawan, Dramaturgi. Bandung: Rosda Karya, 1993. 